\title{
Urban regeneration indicators: a proxy for assessing common
}

\section{good [version 1; peer review: 1 approved with reservations, 1}

\section{not approved]}

\author{
Daniel Gilmour (D), Edward Simpson \\ School of Applied Science, Abertay University, Dundee, Dundee, DD11HG, United Kingdom
}

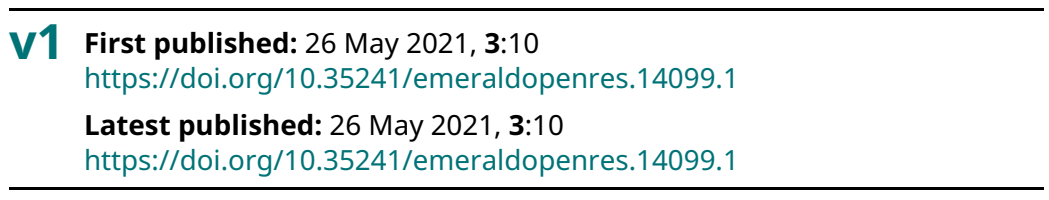

\section{Abstract}

Public realm urban regeneration projects aim to provide facilities for the common good such as improved road systems, public parks, museums and cultural institutions. Driven by political priorities, the expected benefits for society comprise of the proposed regeneration outcomes articulated in a masterplan vision. As a philosophical concept, common good in the context of urban regeneration is explored in this study to understand the expectations for major, longterm regeneration projects and the intended project objectives. In the approach to governance, there should be a relationship between monitoring indicators adopted by the regeneration project as part of the governance framework and their alignment with the common good. These concepts are analysed through a case study of the development and reporting of benchmark indicators established at the start of a major 20-year urban redevelopment in 2010. The monitoring and enhancement concept implemented required indicators to be developed and embedded in the regeneration process to, not only monitor, but also enhance sustainability. The longitudinal case study, at the interim point 10 years since the establishment of these indicators, will evaluate the sustainability of the urban regeneration and evaluate current evidence for the common good. The indicators were developed following the principles of a theme orientated framework in line with the UK and Scottish Government approach at that time. The process of indicator development was iterative, refined and finalised through working closely with local authority, Scottish Enterprise and partnership stakeholders (civic oriented organisations) to capture evidence of progress towards the masterplan vision. Ten years on, conclusions examine whether these indicators could be used a proxy for common good. The conclusion will identify the extent to which we would need to revise indicators to address any gaps to become a more accurate measure of common good.

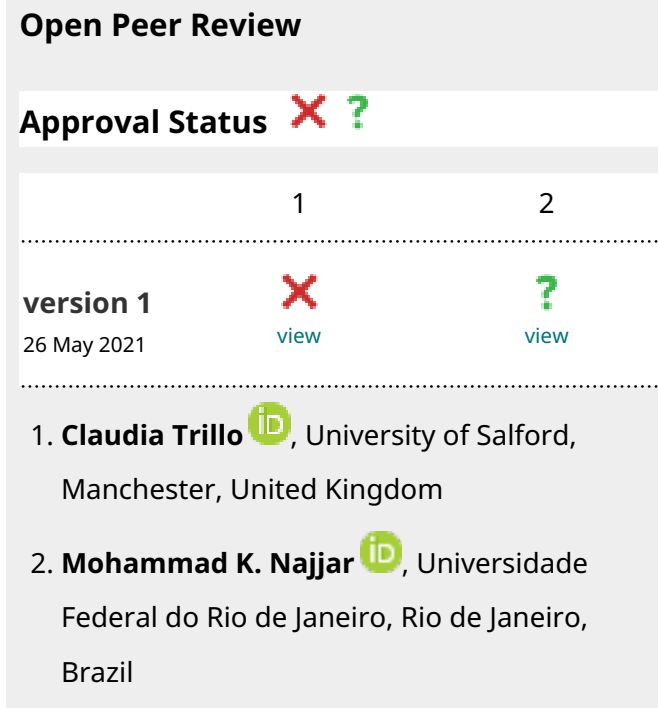

Any reports and responses or comments on the article can be found at the end of the article. 


\section{Keywords}

Common Good, regeneration, indicators, sustainability

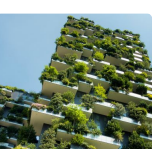

This article is included in the Sustainable Cities

gateway.

Corresponding author: Daniel Gilmour (d.gilmour@abertay.ac.uk)

Author roles: Gilmour D: Conceptualization, Writing - Original Draft Preparation, Writing - Review \& Editing; Simpson E:

Conceptualization, Writing - Original Draft Preparation, Writing - Review \& Editing

Competing interests: No competing interests were disclosed.

Grant information: The author(s) declared that no grants were involved in supporting this work.

Copyright: $\odot 2021$ Gilmour D and Simpson E. This is an open access article distributed under the terms of the Creative Commons Attribution License, which permits unrestricted use, distribution, and reproduction in any medium, provided the original work is properly cited.

How to cite this article: Gilmour D and Simpson E. Urban regeneration indicators: a proxy for assessing common good [version 1; peer review: 1 approved with reservations, 1 not approved] Emerald Open Research 2021, 3:10

https://doi.org/10.35241/emeraldopenres.14099.1

First published: 26 May 2021, 3:10 https://doi.org/10.35241/emeraldopenres.14099.1 


\section{Introduction}

Alternative approaches to sustainability measurement have been explored by the Association of Research in Construction Management (ARCOM) community (e.g. Atkinson, 2008; Forbes et al., 2009; Hearne, 2013; Kawakubo et al., 2018). This paper explores the extent to which urban regeneration sustainability indicators may contribute as a proxy for common good and human well-being, including their ability to measure across spatial-temporal barriers. Establishing what is meant by 'common good' requires complex arguments based in philosophy, exploring how this aligns with the notions of fairness, equity and social justice in relation to political and economic thinking.

\section{Common good}

Does society exist for each one of us, or does each one of us exist for society (Maritain \& Fitzgerald, 1946)? Common good has been presented as a broadly defined concept that had a prominence in the political and social philosophy of ancient Greeks, Catholic Social Teaching (CST) and the philosopher Thomas Aquinas, who was a proponent of the thinking of Aristotle (Argandoña, 2011). Aristotle (1984) presents us with the notion that any community has as a political objective, "good actions, not only life in common" (1984a III, 9, 1280b-1281a). Whilst a general description of the common good covers a good that is created by a community for the community it is possible to be more specific when considering $20^{\text {th }}$ century philosophical thinking. Maritain (1946) provides a description that indicates the common good is, in effect, the combination of goods that the human community share and can include not just physical assets but intangible things such as values, justice and virtues. Dupre' (1994) defines it as "a good proper to, and attainable only by the community, yet individually shared by its members". Common good can therefore be seen both as communal and individual (Dupre, 1993) achieved through, "mutual relationships in and through which human beings achieve their well-being" (Hollenbach, 2002). The breadth of descriptions and definitions have provided refinements over time to reflect changes in society and the increasing influence of economics as an indicator for assessing the success of a society. The focus towards a more entrepreneurial indicator has been considered the basis upon which common good is now achieved (Deneulin \& Townsend, 2007). These descriptions and definitions indicate that the definition of common good covers both microeconomics in relation to the decisions and actions of individuals and businesses as well as macroeconomics covering strategic decisions of countries and governments.

The concept of the common good appears to be increasingly relevant to western contemporary politics and society as interest towards a better understanding of how to improve the well-being of society is gaining interest, with demands to consider alternative approaches to valuing what is important for society (Dasgupta, 2021). It has been argued (Sidgwick, 1874) that as a concept the common good is derived from the combination of shared facilities and interests in which everyone has some form of stakeholder interest. Within this description there are two concepts; the first is of citizenship in relation to supporting the shared interests and the second is of virtue in relation to the level of active engagement with the shared interests. These concepts align with the philosophy of Stoicism as described through the ancient texts of Musonius Rufus and Epictetus. In stoic thinking, individuals seeking to be better citizens do so through taking responsibility for their own actions to help themselves and society through the virtues of wisdom, justice, courage and moderation. It can be argued (Argandoña, 2011) that there is both a good of the person and society. Within this concept a person seeks their own personal good but without doing so at the expense of the common good. There is an expectation that when citizens have been elected to, or appointed to, public office they share in the same values of morality and ethics of that society and therefore as a truly representative citizen of that society make decisions that reflect what they would do as if they were themselves directly affected by the outcomes.

It has been established that the common good is a broad concept, in which a number of different aspects including the actual services of those within the community itself (Maritain \& Fitzgerald, 1946), can be distinguished. Melé (2009) has identified four categories to encompass these aspects and these are presented in Table 1 below:

It is possible to derive two features of the common good based on the understanding of the aspects identified in Table 1: there is a need for sufficient shared agreement on the values of the community and that human well-being means the same to everyone in that community.

Building on the aspect of values, the common good can be considered in relation to the notion of "social value". The Social Value Act 2012 in England and the Local Government in Scotland Act 2003 could be used as suitable examples. The requirements of both of these acts covers the need for those who are contracted to undertake work on behalf of society to present indicators of how their work will contribute towards

\section{Table 1. Aspects of common good (adapted from Mele,} 2009).

\begin{tabular}{|l|l|}
\hline Aspect & Indicators \\
\hline Shared socio-cultural values & $\begin{array}{l}\text { Human rights } \\
\text { Freedom } \\
\text { Safety } \\
\text { Order } \\
\text { Justice }\end{array}$ \\
\hline Organisational influence & $\begin{array}{l}\text { Access to health } \\
\text { Educational provision } \\
\text { Cultural and religious goods } \\
\text { Legal system }\end{array}$ \\
\hline Economic context & Human wellbeing \\
\hline Environmental conditions & $\begin{array}{l}\text { Maintaining the environment } \\
\text { for current and future } \\
\text { generations (sustainability) }\end{array}$ \\
\hline
\end{tabular}


sustainability through evidence indicating the consequential improvements of the work to the social, economic and environmental well-being of the local area. In Scotland this requirement is developed further in that those seeking to do such work are not appointed upon the lowest cost, but assessed against a "best value" model that aligns with the authority's values. Adopting such legal approaches directs those making decisions for the common good to develop communities based on sustainability principles and enabling the needs of the present generation to be met whilst still affording opportunity for future generations to meet their needs (United Nations, 1987). Based on this alignment of common good with sustainability principles it is possible to identify the additional aspects from Table 1, which align with the aim of achieving the common good, since it argues for the rights of future generations when decisions are being made.

\section{The common good principle (CGP)}

The CGP includes the concept of "sustainability" (Melé, 2009) whereby an organization, or in this case study the governing body, can be expected to contribute to the common good. There are different ways to express an organization's mission, one of which may be the use of a strategic vision document or masterplan.

In accordance with the CGP, any team of professional organisers ought to be acting with a sense of "stewardship,". The need for alignment of shared values within the community for the common good extends to its organisations and its stakeholders (Argandoña, 1998). Whilst it is possible to expect an alignment of organisational values with the common good this raises the question of how accountability to the community will be derived, further complicated in that any method of ascertaining and attributing values is based on the flawed assumption that everything that has a value can be measured (Deneulin \& Townsend, 2007). For example, how is the value for the common good to be derived for buildings of a religious nature in an increasingly secular society, yet these buildings contribute to a community culture and identity and accessible to those that wish to use them?

\section{Governance and common good}

Those officials appointed or elected to public office to represent a society's citizens could be described as a governing body. For any governing body that has to present a strategy for its stakeholders to indicate future direction and success it is necessary to create a shared vision to achieve collective action; giving rise to the question what could a "common good" framework look like? Sustainable collective action depends on an institutional framework that directs individuals to socially beneficial decisions (Kuhnert, 2001) and it is of benefit, as indicated previously, that the values of those appointed are such that they manage the collective assets of the community as if these were their own, which has historically been shown to work (Hussain, 2018). The problems of creating a shared vision and achieving collective action for the community increase with the size of the community unless there is an agreed method to make individuals act in their common interest, (Olson, 1971 [1965]). Therefore, in determining a suitable framework for accountability at the initial stages of a new organisation created to have a beneficial impact upon society, the incentives have to align with the values of society. It is therefore understandable that there is reluctance to be truly accountable to society when initiating something for the common good (Kuhnert, 2001). One possible solution could be the adoption of people that can be described as "professional organisers" (Olson, 1971 [1965]) for the formation of collective action groups. These are people that may be elected or appointed and are willing to bear the costs needed to create and maintain a collective good organization that can deliver something for the common good. Whilst Olson does not go on to articulate what is meant by the term, for the purposes of the context of our paper the "regeneration development team" readily fits into such a description as "professional organisers". The purpose of creating this new, accountable organisation is not for the purpose of creating a 'profit' for the community, but to identify and align the shared values and measure the outcomes of the costs to the community against the benefits ultimately achieved in order to determine whether there has been an improvement to human well-being. It is in this context that the mission of the organisation in meeting the needs of its stakeholders provides a framework for the accountability criteria according to which they can be praised and criticized' (Solomon, 2004).

The discussion thus far has provided a framework relating to the "professional organisers" and presented the "organisation" as an intermediate entity to achieve the common good. As such, the purpose of such an organisation goes beyond increasing human wellbeing through effective and efficient deployment of resources as measured against objective metrics associated with goods and services, to recognise the relevant subjective metrics associated with, for example, developing technical skills, intellect and virtues. The difficulties in deriving agreed, fair and just metrics for accountability against subjective criteria for the common good is clearly complex and there are gaps in the theory around such issues (Sison \& Fontrodona, 2012). On that basis any new activity by an organisation set up for the common good to create something for the common good needs to have a suitable, agreed framework for accountability to demonstrate to the community that it has used resources effectively, efficiently and decisions are made in the best interest of the community for success (Kerr, 2007). By way of an example, the relationship of the case study organisation appointed to deliver major positive impact for the community through redevelopment of the city waterfront, combining the need for a framework of accountability covering both objective and subjective criteria. Figure 1 represents the interrelationship between common good concepts, with the organisation in the centre and the aspects of the common good in the social political environment.

\section{Case study: urban regeneration and common good}

Urban regeneration projects provide facilities for the common good such as improved road systems, public parks, museums and cultural institutions. Driven by political priorities, the benefits for society will comprise of the proposed regeneration outcomes articulated in an urban regeneration masterplan vision. The common good is the socio-political context and the 


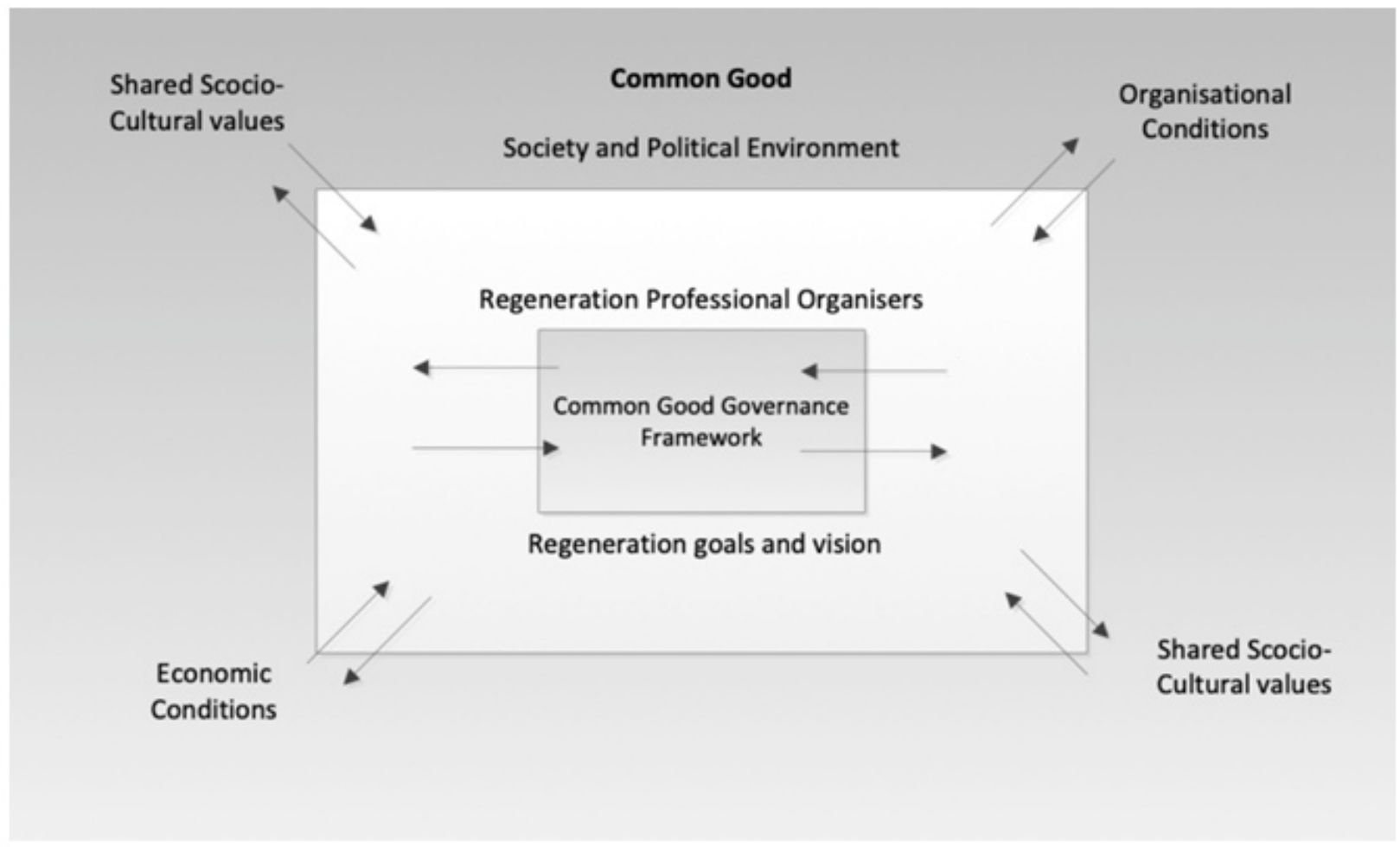

Figure 1. Interrelationship between common good concepts, urban regeneration and the project team.

regeneration vision is the way to operationalise this through the regeneration project organisation and delivery team. The introduction of a regeneration masterplan based on agreed well-being indicators, such as this case study, enables their ability to measure across spatial-temporal barriers. The concept in the context of the regeneration project can be represented diagrammatically where the influence of the common good context drives the regeneration goals and vison, leading to the local authority project team (professional organisers) actions.

The case study incorporates a strategic regeneration project along $8 \mathrm{~km}$ of the River Tay Dundee, Scotland. The £1billion transformation of Dundee City Waterfront is expected to lead to the creation of over 7,000 jobs as well as enhancing the city landscape. The project masterplan was published in 2001 following a large consultation to develop a vision for Dundee. The masterplan incorporates a vision of connecting the city centre with the waterfront. This required the re-alignment of roads and bridge structures and the creation of development plots and civic space will stretch from the existing city centre down to the river.

Published single outcome agreement (SOA) strategic outcomes statements for Dundee were reviewed in the context of the common good. Table 2 presents the mapping of SOA strategic outcomes within a three-level structure of the political common good for the organisation (Sison \& Fontrodona, 2012). Managers should monitor all three levels because if any were lacking, the other two would be unable to fulfil their function.

The common good of the organisation of the regeneration is embedded within a wider common good, that of the political community. Each member of the community can benefit from common good (eudaimonia). The positive influence of the common good occurs at several levels. The regeneration team produces goods and services that society needs. The development of new skill and engagement with stakeholders (subjective dimension) leads to the effectively produced goods and services (objective dimension).

\section{Methods}

Regeneration monitoring framework development Indicators serve as pointers that can be easily identified and recognised as describing sustainability, and help in monitoring the progress towards sustainability. Indicators can provide meaningful information, in a consistent format, to communicate complex information. Through their establishment, users can monitor changes on different time space and scales and, if undertaken in a transparent way, can use them to illustrate connectivity across ranging levels of complexity and scale (Hák, 2007).

Sustainability indicators can operationalise these themes and act as a proxy for common good. 
Table 2. Dundee masterplan and the political common good indicators.

\begin{tabular}{|c|c|}
\hline $\begin{array}{l}\text { (Sison \& Fontrodona, } \\
\text { 2012) }\end{array}$ & Single Outcome Agreement Strategic Outcomes \\
\hline $\begin{array}{l}\text { Level } 1 \\
\text { Material well being }\end{array}$ & $\begin{array}{l}\text { More and better employment opportunities for our people } \\
\text { Our people will be better educated and skilled } \\
\text { Our people will live in strong, popular and attractive communities } \\
\text { Our communities will have high quality and accessible local services and facilities } \\
\text { Our people will live in a low carbon, sustainable city }\end{array}$ \\
\hline $\begin{array}{l}\text { Level } 2 \\
\text { Peace and concorde }\end{array}$ & $\begin{array}{l}\text { Our children will be safe, healthy, achieving, nurtured, active, respected, responsible and included } \\
\text { People in Dundee will have improved physical health and mental well-being and will experience } \\
\text { fewer health inequalities } \\
\text { People in Dundee are able to live independently and access support when they need it } \\
\text { Our communities will be safe and feel safe } \\
\text { Dundee will be a fair and socially inclusive city }\end{array}$ \\
\hline $\begin{array}{l}\text { Level } 3 \\
\text { Cultural values }\end{array}$ & $\begin{array}{l}\text { Dundee will be an internationally recognised city at the heart of a vibrant region } \\
\text { A city renowned for learning and culture }\end{array}$ \\
\hline
\end{tabular}

The regeneration monitoring framework was developed through working with partnership stakeholders and document analysis (Gilmour et al., 2011) and established in 2010 supported by a set of sustainability benchmark indicators for Dundee City Council. The system was designed to utilise SOA meta data to populate indicators in post baseline data compilation and reporting. The indicators are designed to monitor the direct activities on the regeneration project and the city wide/regional impact of the regeneration activities. Key to the adoption of the indicator by Dundee City Council was the ability to collect data without additional resources. To address this, indicators were aligned with existing data collected by the Dundee Waterfront Partnership. This alignment with partners' existing reporting requirements will allow long term collation of the sustainable development benchmark indicator data.

\section{Results}

Regeneration benchmark Indicator trends 2010 -2020

Table 3 presents an overview of the regeneration indicators developed to monitor and enhance the sustainability of the public realm regeneration project. The breadth of the indicator coverage across economic, environmental, and social dimensions of sustainability reflects the masterplan vision and the anticipated scale of the regional regeneration impact as set out in the vision of the masterplan. The use of the SOA data on a regional level lets a long-term monitoring of regeneration benchmark indicator trends to ensure the regeneration indicators continue to go in the desired direction.

The 26 indicators shown in Table 3 represent the regeneration benchmark indicators for Dundee Waterfront. The Indicators were developed from literature and by working with local stakeholders in the Dundee partnership to identify existing data collected as part of SOAs or other statutory duties. This information was matched with Scottish government indicators and UK government indicators for sustainable development. Where this is possible it has been marked with a $*$ to acknowledge its relationship with the national reporting frameworks. Typically, the definition of the indicator required adjustment to be more relevant to Dundee Waterfront.

Due the regional importance of the development and expected regional impact the completed Dundee Waterfront will have on Dundee and its surrounding area there are a number of city-wide indicators included in the benchmark indicators. Data is relevant to the whole of Dundee (city wide), or Dundee Waterfront specific data (direct). This is particularly evident in the economic category where 7 of 10 indicators are city wide, and Social category where 6 out of 9 indicators are based on city wide measures. The results of the trend analysis are indicated in the tables in a similar style to the SOA Data. The desired direction of travel was agreed with stakeholders as part of the indicator development. Of the 26 indicators across the economic, environmental and social categories, 19 indicators have moved in the desired direction, with only 2 indicators moving in the opposite direction.

Trend symbol

$\begin{array}{ll}\text { Indicator moving in desired direction } & \checkmark \\ \text { Indicator showing no significant change } & \sim \\ \text { Indicator moving against desired direction } & \times \\ \text { Not sufficient information } & \ldots\end{array}$

\section{Currency of indicators}

The currency of the 2010 indicator set was reviewed in 2013. This was undertaken through two workshops with Improvement 


\section{Table 3a. Regeneration benchmark Indicators - economic.}

\begin{tabular}{|c|c|c|c|c|c|c|c|}
\hline & $\begin{array}{l}\text { Benchmark } \\
\text { indicators }\end{array}$ & Definition of indicator & Units & $\begin{array}{l}2010 \\
\text { Baseline Data }\end{array}$ & $\begin{array}{l}2020 \\
\text { data }\end{array}$ & $\begin{array}{l}\text { Desired } \\
\text { direction/ } \\
\text { Target }\end{array}$ & Trend \\
\hline $1 a$ & $\begin{array}{l}\text { Demographics* } \\
\text { (City Wide) }\end{array}$ & Population retention & Population number & 146,060 & 149,300 & UP & $\checkmark$ \\
\hline $1 b$ & $\begin{array}{l}\text { Retention of skills base } \\
\text { (City Wide) }\end{array}$ & Graduate retention rate & Graduate population & $33 \%$ & $44.9 \%$ & Up & $\checkmark$ \\
\hline 1c & $\begin{array}{l}\text { Knowledge based } \\
\text { employment } \\
\text { (City Wide) }\end{array}$ & $\begin{array}{l}\text { Knowledge economy } \\
\text { sector jobs }\end{array}$ & $\begin{array}{l}\text { Number of employee } \\
\text { jobs in Knowledge } \\
\text { Intensive sector }\end{array}$ & 36,100 & $34,800^{1}$ & Up & $x$ \\
\hline $1 d$ & $\begin{array}{l}\text { Employment* } \\
\text { (City Wide) }\end{array}$ & Employment rates & $\begin{array}{l}\% \text { of resident working } \\
\text { age population }\end{array}$ & $66.6 \%$ & $68.6 \%$ & Up & $\checkmark$ \\
\hline $1 e$ & $\begin{array}{l}\text { Capacity to stimulate } \\
\text { investment* } \\
\text { (Direct) }\end{array}$ & $\begin{array}{l}\text { Total inward investment } \\
\text { to waterfront }\end{array}$ & $£$ Inward investment & 0 & $68.3 m$ & Up & $\checkmark$ \\
\hline $1 f$ & $\begin{array}{l}\text { Tourism numbers } \\
\text { (City Wide) }\end{array}$ & $\begin{array}{l}\text { Tourists visiting city } \\
\text { centre locations }\end{array}$ & Number & $\begin{array}{l}53,535 \\
72,061\end{array}$ & 830,000 & Up & $\checkmark$ \\
\hline $1 \mathrm{~g}$ & $\begin{array}{l}\text { Tourism } \\
\text { (City Wide) }\end{array}$ & $\begin{array}{l}\text { Level of tourism } \\
\text { expenditure Dundee }\end{array}$ & Expenditure & $£ 130.79$ million & £206 million & Up & $\checkmark$ \\
\hline $1 \mathrm{~h}$ & $\begin{array}{l}\text { Regeneration } \\
\text { (Direct) }\end{array}$ & Increased property value & $\%$ Increase & 0 & $3.5 \%$ & Up & $\checkmark$ \\
\hline $1 \mathrm{i}$ & $\begin{array}{l}\text { Job creation } \\
\text { (Direct) }\end{array}$ & Number of jobs created & Number & 0 & 2143 & UP & $\checkmark$ \\
\hline $1 \mathrm{j}$ & $\begin{array}{l}\text { Economic output* } \\
\text { (City Wide) }\end{array}$ & Economic output & $\begin{array}{l}\text { Gross Value Added (GVA } \\
\text { per head of population }\end{array}$ & 17,866 & $24,104^{2}$ & Up & $\checkmark$ \\
\hline
\end{tabular}

\section{Table 3b. Regeneration benchmark Indicators - environmental.}

\begin{tabular}{|c|c|c|c|c|c|c|c|}
\hline & $\begin{array}{l}\text { Benchmark } \\
\text { indicators }\end{array}$ & Definition of indicator & Units & $\begin{array}{l}2010 \\
\text { Baseline } \\
\text { Data }\end{array}$ & 2020 & $\begin{array}{l}\text { Desired } \\
\text { direction/ } \\
\text { Target }\end{array}$ & \\
\hline $2 a$ & $\begin{array}{l}\text { Green space/ } \\
\text { public space* } \\
\text { (Direct) }\end{array}$ & Local environmental quality & $\begin{array}{l}\text { Green space quality } \\
\text { standard }\end{array}$ & $\begin{array}{l}\text { Not yet } \\
\text { available }\end{array}$ & $\begin{array}{l}\text { Quality greenspace } \\
\text { standard for all public } \\
\text { open space }\end{array}$ & Excellent & $\boldsymbol{v}$ \\
\hline $2 b$ & $\begin{array}{l}\text { Waste* } \\
\text { (Direct) }\end{array}$ & Construction waste recycling & $\begin{array}{l}\% \text { of projects where } \\
\text { waste re used/ recycled } \\
\text { in line with best practice }\end{array}$ & 100 & 100 & $\begin{array}{l}\text { Target - to match } \\
\text { national best } \\
\text { practice }\end{array}$ & $\checkmark$ \\
\hline $2 c$ & $\begin{array}{l}\text { Air* } \\
\text { (Direct) }\end{array}$ & $\begin{array}{l}\text { Air emissions continually } \\
\text { monitored at Union Street } \\
\text { and Seagate }\end{array}$ & $\begin{array}{l}\text { Emissions of , NO2 } \\
\text { average } \mu \mathrm{g} / \mathrm{m} 3\end{array}$ & 59.9 & 42.5 & Down & $\boldsymbol{v}$ \\
\hline $2 d$ & $\begin{array}{l}\text { Water* } \\
\text { (Direct) }\end{array}$ & Per capita water use & I/head/day P.E. & $\begin{array}{l}\text { Not yet } \\
\text { available }\end{array}$ & BREEAM Excellent ${ }^{3}$ & $\begin{array}{l}\text { Target - to match } \\
\text { national best } \\
\text { practice }\end{array}$ & $\cdots$ \\
\hline $2 \mathrm{e}$ & $\begin{array}{l}\text { Noise * } \\
\text { (Direct) }\end{array}$ & Noise level impact & $\begin{array}{l}\text { Number of complaints } \\
\text { related to DCW } \\
\text { construction }\end{array}$ & 0 & 0 & Down & $\sim$ \\
\hline $2 f$ & $\begin{array}{l}\text { Energy* } \\
\text { (Direct) }\end{array}$ & Energy consumption & $\begin{array}{l}\text { Energy use/CO2 per M2 } \\
\text { of property }\end{array}$ & $\begin{array}{l}\text { Not yet } \\
\text { available }\end{array}$ & BREEAM Excellent ${ }^{3}$ & $\begin{array}{l}\text { Target - to match } \\
\text { national best } \\
\text { practice }\end{array}$ & $\cdots$ \\
\hline $2 g$ & $\begin{array}{l}\text { Travel}^{\star} \\
\text { (City Wide) }^{\text {Cita }}\end{array}$ & $\begin{array}{l}\text { Journeys to work and school } \\
\text { made by pubic or active } \\
\text { transport }\end{array}$ & $\%$ Journeys & $15 \%$ & $21 \%$ & Up & $\boldsymbol{v}$ \\
\hline
\end{tabular}


Table 3c. Regeneration benchmark Indicators - social.

\begin{tabular}{|c|c|c|c|c|c|c|c|}
\hline & $\begin{array}{l}\text { Benchmark } \\
\text { indicators }\end{array}$ & Definition of indicator & Units & $\begin{array}{l}2010 \\
\text { Baseline } \\
\text { Data }\end{array}$ & 2020 & $\begin{array}{l}\text { Desired } \\
\text { direction/ } \\
\text { Target }\end{array}$ & \\
\hline $3 a$ & $\begin{array}{l}\text { Housing provision } \\
\text { (Direct) }\end{array}$ & Residential development & $\%$ of residential development & $21 \%$ & $21 \%$ & $21 \%$ & $\checkmark$ \\
\hline $3 b$ & $\begin{array}{l}\text { Health \& Wellbeing* } \\
\text { (City Wide) }\end{array}$ & $\begin{array}{l}\text { Positive and sustained } \\
\text { destinations } \\
\text { (education, higher } \\
\text { education, employment or } \\
\text { training) }\end{array}$ & $\begin{array}{l}\% \text { of school leavers in positive and } \\
\text { sustained destinations }\end{array}$ & $77.8 \%$ & $94.3 \%$ & increase & $\checkmark$ \\
\hline $3 c$ & $\begin{array}{l}\text { Community* } \\
\text { (City Wide) }\end{array}$ & Neighbourhood satisfaction & $\begin{array}{l}\% \text { Residents satisfied with the quality } \\
\text { of and access to local services, } \\
\text { facilities and environment }\end{array}$ & $\begin{array}{l}\text { Quality } \\
97 \% \\
\text { Access 83\% }\end{array}$ & $89 \%$ & Up & $\times$ \\
\hline $3 d$ & $\begin{array}{l}\text { Social Inclusion* } \\
\text { (City Wide) }\end{array}$ & $\begin{array}{l}\text { Accessibility of cultural and } \\
\text { learning opportunities }\end{array}$ & $\begin{array}{l}\text { Percentage of adults who have } \\
\text { participated in a cultural activity or } \\
\text { attended a cultural event or place in } \\
\text { last } 12 \text { months }\end{array}$ & $71 \%$ & $85 \%$ & UP & $\checkmark$ \\
\hline $3 e$ & $\begin{array}{l}\text { Participation and } \\
\text { responsibility } \\
\text { (City Wide) }\end{array}$ & $\begin{array}{l}\text { Participation in sustainable } \\
\text { decision making }\end{array}$ & $\begin{array}{l}\text { Percentage of residents who agree } \\
\text { that people in their community can } \\
\text { influence decisions affecting that } \\
\text { area }\end{array}$ & 0 & $50 \%$ & Up & $\checkmark$ \\
\hline $3 f$ & $\begin{array}{l}\text { Active community } \\
\text { participation* } \\
\text { (City Wide) }\end{array}$ & $\begin{array}{l}\text { Informal and formal } \\
\text { volunteering }\end{array}$ & $\%$ adults who volunteer regularly & $17 \%$ & $21 \%$ & UP & $\checkmark$ \\
\hline $3 g$ & $\begin{array}{l}\text { Acceptability } \\
\text { (Direct) }\end{array}$ & Acceptability to stakeholders & $\%$ & $96 \%$ & - & Up & $\ldots$ \\
\hline $3 h$ & $\begin{array}{l}\text { Confidence } \\
\text { (City Wide) }\end{array}$ & Public perception of Dundee & $\begin{array}{l}\text { Public Perception of Dundee - (Public } \\
\text { Perception of Dundee on a scale of } \\
1-10 \text { ) - SOA Delivery Plan Indicator }\end{array}$ & 6.31 & $6.88^{4}$ & UP & $\checkmark$ \\
\hline $3 \mathrm{i}$ & $\begin{array}{l}\text { Amenity value* } \\
\text { (City Wide) }\end{array}$ & $\begin{array}{l}\text { Public perception of amenity } \\
\text { of Waterfront area }\end{array}$ & Qualitative & N/A & $\begin{array}{l}\text { Green } \\
\text { Flag } \\
\text { Award }\end{array}$ & Excellent & $\ldots$ \\
\hline
\end{tabular}

Notes:

${ }^{1}$ Data from 2015 used as more recent figures not available

${ }^{2}$ Baseline 2010 data units change to allow comparison with 2020 data

${ }^{3}$ BREEAM Excellent obligation for developments considered to be equivalent

${ }^{4}$ Data from 2015 used as more recent figures not available

Service Scotland. This organisation improves the accountability of Local Authorities supporting them to improve efficient and quality of public services. The first workshop at the Scottish government explored different indicator best practice approaches. The Dundee Waterfront sustainable benchmark indicators were presented alongside the Menu of Local Outcome Indicators (Improving Local Outcome Indicators Project 2012) developed by SOLACE Scotland (Society of Local Authority Chief Executives) with input from the Scottish government, and other partnership bodies, improvement Service Scotland and Audit Scotland.

The second workshop at TAYplan Strategic Planning Authority was facilitated by Improvement Service and looked at developing a set of indicators for TAYplan. The workshop discussion regarded indicators' development, Menu of Local
Outcome Indicators, developing indicators of regional impact and drew reference to the benchmark indicators developed for Dundee Waterfront. These two workshops provided confidence in the method of development and the currency of the indicators. This confidence was based on the best practice workshops which invited Abertay to present the indicators and their method of development. Particular reference was made to the waterfront Indicators by the Improvement Service and TAYplan when they considered the criteria for indicator selection and encouraged the use of Menu of Local Outcome Indicators to be utilised.

In December 2017, the council adopted the Dundee Partnership City Plan 2017-2026 consisting of 70 key performance indicators (KPIs). This replaced the SOA indicator framework. The National Performance Framework was developed by the 
Scottish Government for all local authorities. Its development is underpinned by the Scottish Government's commitment to achieving Sustainable Development Goals.

\section{Conclusions}

The provision and maintenance of facilities that serve the common good is a civic relationship underpinned by philosophical positions of the common good as a political community. Aristotle has presented the argument that every community is established with a view to some good (Melé, 2009); this shared good or interest can be found in various communities including business organisations and local authorities. To avoid ambiguity and confusion the preferred language is that of 'interests' if by human good we understand an end which contributes to human flourishing. Arising from this notion is the expectation that all the interests are considered as a constituent of the common good and are part of political deliberation.

For any single facility or shared interest (in our case the major regeneration project), in order to demonstrate achievement for the common good it has to demonstrate that it was for each and every person in the community, at the same time and for the same reason (Argandoña, 2011). It is unlikely that the members of a diversified community will all have the same conception of what their common good is; but through the use of contemporary approaches (e.g. agreed sustainability indicators), it is possible to illicit a shared understanding of what is desired through the co-operation and participation of appropriate representatives of the community.

At the interim stage, 10 years after establishment, the majority of these indicators have moved in the desired direction to achieve the final regeneration vision. This has been due to the engagement of the project team in identifying and enhancing the sustainability of the development at infrastructure stage where road, parks and museums have been redeveloped. In assessing whether these indicators could be used a proxy for common good the research indicates that the indicators map directly on to the Sison \& Fontrodona (2012) framework as an appropriate and successful measure of common good. Therefore, it is possible to deduce that the indicators are, in their entirety, a suitable proxy for the common good.

The sustainability indicators, which encompass the societal and political objectives of the redevelopment, reflect well the components of common good as set out in the paper. It is concluded that this is primarily for three reasons, firstly the nature of the three pillars of sustainability fit well with the object of common good philosophy as per the Sison and Fontrodona framework. Secondly the indictors were developed in close coordination with the professional organisers where the process of indicator development was iterative, refined and finalised through close working with local authority, Scottish enterprise and partnership stakeholders (civic oriented organisations) to capture evidence of progress towards the masterplan vision. Thirdly, the design to utilise SOA meta data consolidates the match between common good and the redevelopment goals as described as SOA.

\section{Data availability}

The data is publicly available from Dundee City Council and Dundee Partnership documentation: https://www.dundeecity.gov. uk/dundee-partnership/
Argandoña A: The Stakeholder Theory and the Common Good.J Bus Ethics. 1998; 17(9): 1093-1102.

Publisher Full Text

Argandoña A: The Common Good. SSRN Electronic Journal. 2011. Publisher Full Text

Aristotle: Politics. In: J Barnes (Ed.). The Complete Works of Aristotle Volume 2. Princeton, NJ: Princeton University Press. 1984.

Atkinson G: Sustainability, the capital approach and the built environment Building Research and Information. 2008; 36(3): 241-247.

Publisher Full Text

Dasgupta P: The Economics of Biodiversity: The Dasgupta Review. Full Report. (London: HM Treasury). 2021.

Reference Source

Deneulin S, Townsend N: Public goods, global public goods and the common good. Int J Soc Econ. 2007; 34(1/2): 19-36.

Publisher Full Text

Dupré L: The common good and the open society. The Review of Politics. 1993; 55(4): 687-712.

Reference Source

Dupre' L: The common good and the open society. In: Douglas, RB and Hollenbach, D (Eds.). Catholicism and Liberalism. Cambridge: Cambridge University Press, 1994; 172-95.

Forbes D, Smith SD, Horner M: Risk and its analysis in the sustainability assessment of the built environment. In: Dainty, ARJ (Ed.). Proceedings 25th Annual ARCOM Conference. 7-9 September 2009, Nottingham, UK Association of Researchers in Construction Management, 2009; 2: 823-33. Reference Source

Gilmour DJ, Blackwood DJ, Banks L, et al.: Sustainable development indicators for major infrastructure projects. Proceedings of the Institution of Civil Engineers: Municipal Engineer. 2011; 164(1): 15-24.

Publisher Full Text

Hák T, Moldan B, Dahl AL: Sustainability indicators: a scientific assessment London: Island Press. 2007.

Reference Source

Hearne R: Realising the right to the city: Developing a human rights based framework for regeneration of areas of urban disadvantage. Int J Law Built Environ. 2013; 5(2): 172-187.

Publisher Full Text

Hollenbach D: The Common Good and Christian Ethics. Cambridge:

Cambridge University Press. 2002

Publisher Full Text

Hussain W: The Common Good. 2018. [Accessed 17 January 2020]. Reference Source

Kawakubo S, Murakami S, Ikaga T, et al:: Sustainability assessment of cities: SDGs and GHG emissions. Build Res Inf. 2018; 46(5): 528-539.

Publisher Full Text

Kerr J: Watershed management: Lessons from common property theory. Int 
J Commons. 2007; 1(1): 89-109.

Publisher Full Text

Kuhnert S: An evolutionary theory of collective action: Schumpeterian entrepreneurship for the common good. Const Political Econ. 2001; 12(1): 13-29.

Publisher Full Text

Maritain J: The Person and the Common Good. Notre Dame, IN: University of Notre Dame Press. 1946

Reference Source

Maritain J, Fitzgerald J]: The person and the common good. Rev Polit. 1946; 8(4): 419-455.

Publisher Full Text

Melé D: Integrating personalism into virtue-based business ethics: The

personalist and the common good principles. J Bus Ethics. 2009; 88(1):

227-244.

Publisher Full Text
Olson M: The Logic of Collective Action Cambridge. Mass.: Harvard University Press. 1971.

Reference Source

Sidgwick H: The Methods of Ethics. London: Macmillan and Co.; 7th edition, 1907, London: Macmillan; 7th edition reprinted by Indianapolis: Hackett, [1981] 1874.

Reference Source

Sison AJG, Fontrodona J: The common good of the firm in the AristotelianThomistic tradition. Bus Ethics Q. 2012; 22(2): 211-246.

Publisher Full Text

Solomon RC: Aristotle, ethics and business organizations. Organization Studies. 2004; 25(6): 1021-1043.

Publisher Full Text

United Nations: Report of the World Commission on Environment and Development. (The Brundtland Report). 1987. [Accessed 17 January 2020]. Reference Source 


\section{Open Peer Review}

\section{Current Peer Review Status: $\mathrm{X}$ ?}

\section{Version 1}

Reviewer Report 08 February 2022

https://doi.org/10.21956/emeraldopenres.15187.r27950

(C) 2022 Najjar M. This is an open access peer review report distributed under the terms of the Creative Commons Attribution License, which permits unrestricted use, distribution, and reproduction in any medium, provided the original work is properly cited.

\section{Mohammad K. Najjar}

Escola Politécnica, Departamento de Construção Civil, Universidade Federal do Rio de Janeiro, Rio de Janeiro, Brazil

This study explores the common good in the context of urban regeneration to understand the expectations for major, long-term regeneration projects and the intended project objectives. The work is in the scope of the journal, however, redaction and structure should be improved as indicated below, especially the methods should be clearer; the author is recommended to identify and practice sophisticated objectives for a journal publication. The author must justify the following points:

Comment 1: Abstract is too long. It should be rewritten to have one sentence per each: context and background, motivation, hypothesis, methods, results, conclusions.

Comment 2: I couldn't identify the novelty of the paper. The paper should be revised to highlight novelties. Please consider that this lack of novelty starts with the Abstract, Introduction, and Conclusion.

Comment 3: Several references are outdated, hence, a deep analysis of recent scientific papers covering only the topic and leading to the submission hypothesis based on the gap analysis of the previously and recent published research is required.

Comment 4: The proposed methods are not outlined with the necessary vigor. The author needs to include sufficient methodological details in the paper and elaborate on the produced results from the proposed methods. Some sections must be added to make this section clearer for the readers. It is not clear for me if this work was built based on a case study, or it was built based on a proposed approach validated within a case study.

Comment 5: The Discussion Section is missing. The author needs to understand that his research is not only a case study but is also based on scientific questions. At this level of the study, the author must differentiate between the results of this work based on; the proposed approach; and 
the applied case study.

Comment 6: The Conclusion section is missing some necessary details. For example, the author needs to highlight the novelty and the materials and methods used in this work. Then the author should present the results of this work. Eventually, a summary of the limitations of this research as well as the recommendation for future works should be indicated.

Comment 7: Proofreading by a native speaker should be conducted to improve clarity and organization quality. Besides, don't start with the title and subtitle without a text in between.

Is the work clearly and accurately presented and does it cite the current literature? No

Is the study design appropriate and is the work technically sound? Partly

Are sufficient details of methods and analysis provided to allow replication by others? No

If applicable, is the statistical analysis and its interpretation appropriate? Partly

Are all the source data underlying the results available to ensure full reproducibility? Partly

Are the conclusions drawn adequately supported by the results? Partly

Is the argument information presented in such a way that it can be understood by a nonacademic audience?

No

Does the piece present solutions to actual real world challenges?

Not applicable

Is real-world evidence provided to support any conclusions made?

Not applicable

Could any solutions being offered be effectively implemented in practice?

Not applicable

Competing Interests: No competing interests were disclosed.

Reviewer Expertise: Architectural and Urban planning, Construciton Civil, BIM, LCA

I confirm that I have read this submission and believe that I have an appropriate level of expertise to confirm that it is of an acceptable scientific standard, however I have 
significant reservations, as outlined above.

Reviewer Report 12 January 2022

https://doi.org/10.21956/emeraldopenres.15187.r27875

(C) 2022 Trillo C. This is an open access peer review report distributed under the terms of the Creative Commons Attribution License, which permits unrestricted use, distribution, and reproduction in any medium, provided the original work is properly cited.

\section{Claudia Trillo}

School of Science, Engineering and Environment, University of Salford, Manchester, United Kingdom

\section{General comments}

This is a very interesting work, and timely too. Worldwide, common good is gaining momentum due to the pandemic. In the UK context, social value is becoming more and more popular following the Social Value Act and related further legislation and documents (Procurement Policy Note PPN 06/20 - Taking Account of Social Value in the Award of Central Government Contracts; https://www.gov.uk/government/publications/the-construction-playbook).

However, some improvements would make this a stronger paper:

Some relevant scholarship omitted. Including Amitai Etzioni is essential. Some suggestions: A. Etzioni (ed.):The Essential Communitarian Reader, Lanham, Rowman and Littlefield Publishers, Inc. (1998) ${ }^{1}$; A. Etzioni: The Road to the Good Society, New York, Basic Books $(2001)^{2}$; T.A. Spragens: Communitarian Liberalism, in: Etzioni A. (1995) (ed.) New Communitarian Thinking, Charlottesville and London: University Press of Virginia $(1995)^{3}$.

Stefano Zamagni and Luigino Bruni could be also included: S. Zamagni: L'economia del bene comune, Roma, CittàNuova Editrice (2007) ${ }^{4}$, https://cup.columbia.edu/book/civileconomy/9781911116004; Civil Economy. Another Idea of the Market. Luigino Bruni and Stefano Zamagni ${ }^{5}$. https://www.scientific.net/AEF.11.303

All these authors are discussed in the introduction of:

Trillo, C. (2014). Urban Regeneration and New Partnerships among Public Institutions, Local Entrepreneurs and Communities. In Advanced Engineering Forum (Vol. 11, pp. 303-313).

Trans Tech Publications, Ltd. https://doi.org/10.4028/www.scientific.net/aef.11.3036.

Evaluation of urban policies rests on a very specific theoretical and methodological framework. Rather than "spatial-temporal barriers" (page 3 and page 5), evaluation theories mention ex-ante, ongoing and ex-post, or approaches such as "developmental evaluation" ( https://www.guilford.com/books/Developmental-Evaluation/Michael-QuinnPatton/9781606238721) 7 .

The case study needs more clarity, including if the researchers contributed to the decision 
making process, how findings have been verified and tested for transferability.

Some typos: Figure 1, page 5, Shared Scocio-cultural values twice, I believe it is sociocultural values. Page 9, second column, indictors, I believe it should be indicators. I also think that "could be used a proxy" should be "could be used AS a proxy" $5^{\text {th }}$ row page 9 , second column.

Specific comments.

Introduction section

"Alternative approaches to sustainability measurement have been explored by the ARCOM". I would delete this sentence, because massive scholarship exists on measuring sustainability and ARCOM is just one of them.

"Including their ability to measure across spatial-temporal barriers". I would rephrase this. Policy evaluation is aimed at assessing impacts at different stages of the policy implementation, before they are implemented with the aim to estimate their potential impact, during the implementation stages to monitor their effectiveness, and after they have been implemented, normally to derive lessons for future programming cycles. Indicators are conceived with the aim of enabling a full evaluative cycle. Some approaches, such as developmental evaluation (DE), revolve around the decision-making process, and are therefore intrinsically dynamic.

"Common good" subsection.

This section gives a sort of utilitarian interpretation of common good. It seems that "Community" is a close-knitted community related concept. Instead, common good (Etzioni, The Encyclopedia of Political Thought, First Edition. Edited by Michael T. Gibbons. (C) 2015 John Wiley \& Sons, Ltd. Published 2015 by John Wiley \& Sons, Ltd. DOI: 10.1002/9781118474396.wbept0178²) "includes both goods that serve no identifiable particular group, as well as those that serve members of generations not yet born." As such, the common good is not the same as the stakeholders interests, or residents' interest. Table 1 does not even mention, "Equity". This is in contradiction with the Dasgupta Review approach that emphasises systemic interconnections at all levels, from the natural domain (biodiversity) to governance and institutions. On the other hand, Social Value as per the Social Value Act 2012 is deeply intertwined with the idea of "Value for Money" and with the idea of serving the interests of those, who do have a stake. Social Value is much narrower than Common Good and more in-depth discussion about differences and similarities would be useful. In fact, Social Value rests on Cost Benefit Analysis assessment techniques, including TOM framework, which are eminently monetary techniques and not quanti-qualitative evaluation methods. Finally, in this subsection the authors argue the alignment of common good and sustainability principles, although this nexus is not clearly demonstrated. In Table 1, indicators are general criteria which are not exhaustive of neither what common good, nor what sustainability should encompass. It is worth reminding that an indicator in the evaluative theory is a tool for measuring level of attainment.

"The Common Good Principle (CGP)" section

This section rests on literature within the field of business economics. This creates confusion in the wording, even the term "sustainability" as used in this section collides with the Brundtland report definition given in the previous one. 
Governance and common good.

In Western democratic countries, urban regeneration processes are normally dealt within an institutional framework, typically steered by local authorities, within a range of guidance and constraints deriving from other public authorities (environmental authorities, transport authorities, etc) and normally involve a variety of actors, including private investors, entrepreneurs, civic society, local associations, etc. The idea of common good is not always the driver of the project, this should be subject to evaluation, although on theory, the common good should be emanated by the democratically elected political body. In the real world, no planner would ever come up with a strategy which wasn't stemming from a political will, but this political will is not necessarily the common good. Again, the confusion stems from the definition of common good, it seems that "it has used resources effectively, efficiently and decisions are made in the best interest of the community for success", but this is not the common good in the Etzioni definition, otherwise all cities in democratic countries would be just, liveable, etc etc whilst unfortunately this is not the case.

Case study: urban regeneration and common good.

The case study in itself is interesting, but it needs more explanation. I suggest that a few maps and drawings, showing the context, illustrating the case, and what sort of infrastructure we are talking about, including some key- data giving the gist of the scale (hectares, investments), would be very helpful. Second, it would be essential to clarify the role of the researchers. For example: "Published single outcome agreement (SOA) strategic outcomes statements for Dundee were reviewed in the context of the common good." Who did this? The researchers? Or was this an initiative that the City of Dundee decided to undertake? If the second, were the researchers acting as consultants for the City? Furthermore, a couple of lines clarifying what a SOA is, what are the usual contents for a SOA, and which is the legal basis, would be very helpful to international readers.

Methods

Regeneration monitoring framework development

The sentence "Sustainability indicators can operationalise these themes and act as a proxy for common good" deserves more explanation. The discussion recalls Table 2 . Outcomes in this table are not outcomes, they are criteria. Beneficiaries are blurred. "More and better employment opportunities for "our" people" is an example, who are those called "Our people"? Are they Dundee residents? Scottish citizens? Residents in the regional city? People from the UK? Immigrant? Homeless?

Results.

More clarification on the role of the researchers needed. A couple of examples. "Table 3 presents an overview of the regeneration indicators developed to monitor... etc". Developed by whom? By the local planners? By the researchers? If by the second, did they act as consultants or advisors for the city?

Same below. "The 26 indicators shown in Table 3 (...) were developed from literature and by working with local stakeholders in the Dundee partnership". Who developed these 26 indicators, when and for what purpose? Were the researchers playing the role of advisors for the City? In which role and based on which authority did they work with local stakeholders?

Regarding Table 3, this is not what I would have expected from a Table seeking to embed the 
concept of common good. Equity is not mentioned, indicators useful to monitor gentrification are not included. Nothing is said on levels of housing affordability. This in a situation in which the indicator number $1 \mathrm{~h}$ clearly shows an increase in the property value equal to 3,5\% (incidentally, I would expect a benchmark to be able to estimate the relative and not the absolute property value increase). Some inconsistencies across indicators should be explained, for example, how is it possible that visitors grew from 53,000 (or 72,000 ?) to 830,000 in 10 years, but the expenditure only grew from $£ 130 \mathrm{M}$ to $£ 206 \mathrm{M}$ ? This should be explained.

Regarding the environmental indicators, biodiversity is not included, no indicator shows the quantity of green areas and permeable surfaces, or the number of trees. Regarding the social indicators. Social inclusion cannot be measured by checking the percentage of cultural and learning opportunities. See EUROSTAT https://ec.europa.eu/eurostat/web/employment-and-socialinclusion-indicators/social-protection-and-inclusion/social-inclusion.

There are no indicators on social diversity in terms of age, race, social mix e.g. how many families living in the area, etc. Mentioning what best practices for the selection of indicators have been used would be essential, as well as clarifying whether an independent evaluator checked the final set of indicators.

This subsection concludes by mentioning that in December 201770 KPIs replaced the SOA indicator framework. Something should be said in the merit of these 70 KPIs, what sort of indicators, how related to the SOA indicators. It is mentioned that the development on this new KPI is underpinned by the Scottish Government's commitment to achieving the UN Agenda 2030 goals, but no further discussion sheds light on this nexus, and on the nexus between SOA, KPI and SDGs targets. This instead needs to be expanded.

Conclusions

No evidence that the redevelopment goals as described as SOA are a reflection of the concept of common good, nor that by using a set of indicators established to monitor some sustainability aspects, the common good is automatically pursued.

\section{References}

1. Etzioni A: The Essential Communitarian Reader. Rowman and Littlefield Publishers, Inc. 1998.

2. Etzioni A: The Road to the Good Society. New York, Basic Books. 2001.

3. Etzioni A: New Communitarian Thinking, Charlottesville and London. University Press of Virginia. 1995.

4. Zamagani S: The economy of the common good. Reference Source

5. Bruni L, Zamagni S: Civil Economy. Agenda Publishing. Reference Source

6. Trillo C: Urban Regeneration and New Partnerships among Public Institutions, Local

Entrepreneurs and Communities. Advanced Engineering Forum. 2014; 11: 303-313 Publisher Full Text

7. Patton MQ: Developmental Evaluation. Applying Complexity Concepts to Enhance Innovation and Use. 2010.

8. Gibbons MT: The Encylopedia of Political Thought. John Wiley. 2015.

Is the work clearly and accurately presented and does it cite the current literature? Partly 
Is the study design appropriate and is the work technically sound?

Partly

Are sufficient details of methods and analysis provided to allow replication by others? Partly

If applicable, is the statistical analysis and its interpretation appropriate?

Not applicable

Are all the source data underlying the results available to ensure full reproducibility? Partly

Are the conclusions drawn adequately supported by the results?

Partly

Is the argument information presented in such a way that it can be understood by a nonacademic audience?

Yes

Does the piece present solutions to actual real world challenges?

Yes

Is real-world evidence provided to support any conclusions made?

Yes

Could any solutions being offered be effectively implemented in practice?

Yes

Competing Interests: No competing interests were disclosed.

Reviewer Expertise: Urban design and planning, public policies evaluator, architect

I confirm that I have read this submission and believe that I have an appropriate level of expertise to state that I do not consider it to be of an acceptable scientific standard, for reasons outlined above. 